\title{
Vulvar Cancer pM1 TNM Finding v8
}

National Cancer Institute

\section{Source}

National Cancer Institute. Vulvar Cancer pM1 TNM Finding v8. NCI Thesaurus. Code C139597.

Vulvar cancer with distant metastasis (including pelvic lymph node metastasis). (from AJCC 8th Ed.) 